\title{
Pengaruh Akuisisi dan Right Issue terhadap Abnormal Return Saham
}

\author{
Elsye Fatmawati \\ Universitas Pelita Bangsa \\ elsye@pelitabangsa.ac.id \\ Laela Nur Azizah \\ Universitas Pelita Bangsa \\ laelana@gmail.com
}

\begin{abstract}
Rights issues and acquisitions are important information for shareholders that can be used to gain future profits and measure market reactions. This reaction can be measured using an abnormal return. This study aims to see whether there are significant differences before the acquisition and rights issues. The population in this study were companies listed on the IDX that carried out acquisitions and rights issues in 2015-2019. This research is a descriptive study using quantitative methods. The sample selection technique in this study is purposive sampling. By following the predetermined criteria, 9 companies were selected as samples. The type of data used is secondary data from yahoo finance 2015-2019, daily stock price data, and daily Composite Stock Price Index (IHSG) (Close Price). Hypothesis testing Paired Sample T-Test and Wilcoxon Signed Rank Test using the SPSS 22.0 program. The results of this study indicate that there is no significant difference in returns in the period before and after the announcement of the acquisition and the rights issue.
\end{abstract}

Keywords : abnormal return, acquisition, rights issue, the stock price

\section{PENDAHULUAN}

Era global saat ini, perusahaan harus menghadapi kompetisi global yang ketat, serta perubahan-perubahan di sektor lain yang dapat mempengaruhi ekonomi. Hal ini menuntut perusahaan untuk memiliki sebuah korporasi yang kokoh, strategi yang tepat dan mumpuni, juga manajemen yang handal agar mampu bertahan dan berkembang di pasar nasional dan pasar internasional. Nick Godfrey (2008) menjelaskan bahwa persaingan menjadi sangat penting dalam operasi pasar, sehinga dapat mendorong inovasi, produktivitas dan pertumbuhan perusahaan. Salah satu strategi tersebut yaitu melakukan ekspansi eksternal seperti penggabungan dua usaha (business combination). Salah satu penggabungan usaha yang menjanjikan yaitu dengan dilakukanya merger dan akuisisi. Merger dan akuisisi mampu membawa keuntungan bagi keadaan ekonomi suatu negara. Merger dan akuisisi menjadi sebuah strategi dengan jalur alternatif pertumbuhan dari luar perusahaan (external growth) untuk tumbuh dan berkembang secara dinamis.

Tren merger dan akuisisi global sejak tahun 2014 semakin membaik. Pada tahun 2018 nilai merger dan akuisisi global meningkat sekitar 7\% yang mendekati rata-rata lima tahun terakhir meskipun volume menurun sebesar 3\% dengan sekitar 35.800 transaksi. Terjadinya merger dan akuisisi dikarenakan sejumlah faktor, termasuk peningkatan 
volatilitas di pasar ekuitias, penurunan penilaian dan ketidakpastian makroekonomi dan politik. Memasuki tahun 2019 pada kuartal pertama volume merger dan akuisisi turun menjadi 15.400 kesepakatan. Perang dagang, Brexit, melemahnya ekonomi China, perkiraan pertumbuhan yang lebih lambat, dan indikator ekonomi lainya yang mempengaruhi sentimen di pasar modal (www.bcg.com).

Transaksi merger dan akuisisi di Indonesia mengalami tren meningkat mulai tahun 2017 hingga 2019 terutama dengan meningkatnya investasi asing dan konsolidasi domestik di sektor keuangan dan konsolidasi di sektor e-commerce oleh berbagai perusahaan teknologi dan aplikasi (www.kppu.go.id). Darlis (2011) menyatakan bahwa perubahan terhadap harga saham menunjukkan adanya perubahan tingkat kemakmuran pemegang saham yang diukur dengan abnormal return positif yang diperoleh pemegang saham. Berikut peneliti tampilkan gambar pengumuman merger dan akuisisi di Indonesia selama tahun 1990 sampai tahun 2019.

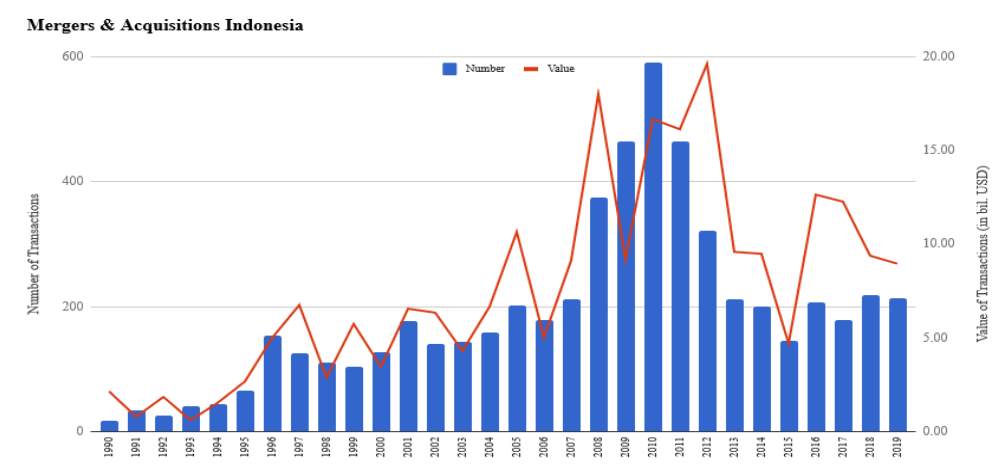

Gambar 1. Merger dan Akuisisi di Indonesia Tahun 1990-2019

Sumber : Website institution of merger, acquisition and alliances.

Pengumuman merger dan akuisisi tertinggi di Indonesia terjadi pada tahun 2010 dimana transaksi yang dilakukan hampir mencapai 600 transaksi. Hal tersebut merupakan imbas dari afiliasi strategi yang dirancang untuk menghadapi persaingan global yang makin menguat. Ditambah dengan adanya perdagangan bebas seperti Asean Free Trade Area (AFTA) membuat persaingan usaha semakin ketat sehingga membuat perusahaanperusahaan di berbagai sektor industri berupaya untuk mempertahankan eksistensinya dengan melakukan merger dan akuisisi. Berikut peneliti tampilkan data akuisisi yang dilakukan oleh perusahaan yang terdaftar di Bursa Efek Indonesia selama tahun selama 5 tahun terakhir.

Tabel 1. Jumlah Perusahaan yang Melakukan Akuisisi di BEI periode 2015-2019

\begin{tabular}{ccc}
\hline No & Tahun & $\begin{array}{l}\text { Jumlah } \\
\text { perusahaan }\end{array}$ \\
\hline 1 & 2015 & 5 \\
\hline 2 & 2016 & 9 \\
\hline 3 & 2017 & 8 \\
\hline 4 & 2018 & 17 \\
\hline 5 & 2019 & 6 \\
\hline & Total & 52 \\
\hline
\end{tabular}

Sumber: kppu 
Transaksi merger akuisisi di Indonesia mengalami tren meningkat mulai tahun 2017 hingga 2019 terutama dengan meningkatnya investasi asing dan konsolidasi domestik di sektor keuangan dan konsolidasi di sektor e-commerce oleh berbagai perusahaan teknologi dan aplikasi (www.kppu.go.id). Tabel 1. menunjukan bahwa perusahaan yang terdaftar di Bursa Efek Indonesia atau emiten yang melakukan akuisisi di tahun 2015 hanya berjumlah 5 perusahaan, kemudian naik menjadi 9 perusahaan pada tahun 2016 dan naik menajdi 8 di tahun 2017. Tahun 2018 juga meningkat yaitu 17 perusahaan, tetapi tren akuisisi pada perusahaan yang terdaftar di Indonesia menurun pada tahun 2019 dengan hanya 6 perusahaan. Hal ini menunjukan bahwa tren akuisisi meningkat mulai tahun 2017 sampai 2019 terjadi pada semua perusahaan di Indonesia, tetapi untuk perusahaan yang terdaftar di Bursa Efek Indonesia mengalami tren mulai meningkat pada tahun 2016 dan menurun pada tahun 2019. Menurut Tarigan (2015) bahwa istilah merger menjadi semakin populer semenjak merger empat bank milik pemerintah yang kemudian menghasilkan Bank Mandiri pada bulan Juli 1999. Akuisisi merupakan bentuk pengambilalihan perusahaan oleh perusahaan lain biasanya lebih besar ukuranya dari perusahaan yang diambil alih yang menyebabkan berpindahnya kendali atas perusahaan yang diambil alih tersebut. Apabila strategi penggabungan usaha dilakukan berdasarkan pada motif akuisisi, maka perusahaan akuisitor dapat menaikan nilai perusahaan atau menambah kemakmuran pemegang saham.

Persaingan usaha yang semakin ketat direspon berbeda-beda oleh perusahaan. Sebagai alternatif, perusahaan dapat mengembangkan usahanya melalui investasi, ekspansi, ataupun meningkatkan modal kerja. Perusahaan dalam mengembangkan usaha membutuhkan sumber dana yang besar untuk membiayai kebutuhan usahanya. Bagi perusahaan yang sudah go public atau listing di Bursa Efek Indonesia dapat melakukan penawaran umum terbatas (right issue) yang dapat ditawarkan kepada pemegang sahamnya terlebih dahulu. Right issue merupakan penawaran hak untuk membeli saham tambahan yang diberikan kepada pemegang saham lama dengan harga saham yang lebih rendah dari harga saat ini, sehingga investor tertarik untuk membeli.

Berikut peneliti tampilkan data right issue yang dilakukan oleh perusahaan yang terdaftar di Bursa Efek Indonesia selama tahun selama 5 tahun terakhir.

Tabel 2. Jumlah Perusahaan yang Melakukan Right Issue di BEI periode 2015-2019

\begin{tabular}{ccc}
\hline No & Tahun & Jumlah perusahaan \\
\hline 1 & 2015 & 17 \\
\hline 2 & 2016 & 26 \\
\hline 3 & 2017 & 24 \\
\hline 4 & 2018 & 24 \\
\hline 5 & 2019 & 17 \\
\hline & Total & 105 \\
\hline
\end{tabular}

Sumber: ksei

Selama 5 tahun terakhir, tren right issue pada perusahaan yang terdaftar di Indonesia berfluktuasi. Tahun 2015 ada 17 perusahaan yang melakukan right issue, kemudian mengalami tren naik menjadi 26 perusahaan pada tahun 2016. Tahun 2017 dan 2018 turun 2 angka menjadi 24 perusahaan dan terus pada tahun 2019 kembali turun menjadi 17 perusahaan. Penurunan ini terpengaruh oleh kondisi global yang menekan 
Indeks Harga Saham Gabungan (IHSG), sehingga beberapa emiten menahan untuk melakukan aksi korporasi. Ketika IHSG terkoreksi, para investor cenderung wait and see, yaitu menunggu kesempatan yang tepat. Hal ini menandakan bahwa investor membutuhkan informasi yang banyak dan tepat agar keputusan yang diambil lebih efektif, termasuk informasi aksi korporasi dari perusahaan (www.kontan.co.id).

Publikasi informasi mengenai akuisisi dan right issue bertujuan untuk mempengaruhi nilai perusahaan dan menilai reaksi pasar modal. Informasi tersebut diserap oleh investor sebagai infomasi penting yang dapat digunakan untuk mendapatkan keuntungan di masa mendatang. Reaksi dari pasar modal atas publikasi informasi dari perusahaan dapat diukur dengan menggunakan abnormal return saham. "Perubahan atau selisih yang terjadi pada sekuritas perusahaan yang melakukan akuisisi dan right issue dapat berupa selisih positif dan selisih negatif. Hal ini terefleksi dari situasi yang diharapkan oleh investor yaitu, dimana ketika pasar memberikan respon positif dengan abnormal return yang positif. Berarti bahwa investor akan memperoleh keuntungan di atas normal pada saat itu, karena return yang sesungguhnya lebih besar dari return yang diharapkan. Namun jika terjadi sebaliknya maka dapat dikatakan bahwa pasar memberikan respon negatif dan abnormal return yang negative (Lianawati \& Darmayanti, 2015)

Beberapa hasil penelitian terdahulu terkait dengan abnormal return sebelum dan sesudah pengumuman akuisisi dan right issue menyebutkan bahwa akuisisi dan right issue memiliki kandungan informasi yang membuat pasar bereaksi. Menurut Astria (2012), berdasarkan penelitian yang telah dilakukan diperoleh kesimpulan bahwa ada perbedaan signifikan abnormal return pada periode sebelum dan sesudah peristiwa merger dan akusisi. Penelitian yang dilakukan Joga (2010) menyimpulkan bahwa terdapat perbedaan return saham dan abnormal return saham sebelum dan sesudah pengumuman right issue. Aktivitas volume perdagangan dan likuiditas saham juga mengalami perbedaan sebelum dan sesudah pengumuman right issue. Epriyeni (2014) memberikan kesimpulan dari penelitian tersebut yaitu terdapat perbedaan abnormal return sebelum, saat dan sesudah pengumuman merger dan akuisisi serta terdapat perbedaan abnormal return sebelum, saat dan sesudah pengumuman right issue.

Penelitian yang dilakukan Hidayat (2013) memberikan hasil bahwa tidak ada perbedaan sebelum dan sesudah pengumuman merger dan akuisisi. Pratama (2014) menyimpulkan bahwa tidak terdapat perbedaan abnormal return signifikan secara statistik sebelum maupun sesudah peristiwa right issue. Temuan tersebut diketahui bahwa dampak pengumuman akuisisi dan right issue terhadap abnormal return tidak memberikan satu simpulan yang sama karena ada yang memberikan pengaruh dan ada juga yang tidak memberikan pengaruh. Berdasarkan penelitian sebelumnya, maka penelitian ini mengamati kembali kandungan informasi yang terdapat dalam pengumuman akuisisi dan right issue. Penelitian ini dilakukan pada perusahaan di Bursa Efek Indonesia yang melakukan akuisisi right issue selama periode 2015 ampai 2019.

\section{LANDASAN TEORI}

\section{Akuisisi}

Menurut Sudana (2011) Akuisisi adalah penggabungan dua perusahaan yang mana perusahaan akuisitor membeli sebagian saham perusahaan yang diakuisisi, sehingga pengendalian manajemen perusahaan yang diakuisisi berpindah kepada perusahaan akuisitor, sementara kedua perusahaan masingmasing tetap beroperasi sebagai suatu 
badan hukum yang berdiri sendiri. Menurut Haryani (2013) akuisisi dapat dibedakan dalam tiga kelompok besar sebagai berikut :

a. Akuisisi horizontal Akuisisi yang dilakukan oleh suatu badan usaha yang masih berkecimpung dalam bidang bisnis yang sama.

b. Akuisisi vertikal Akuisisi yang dilakukan oleh suatu badan usaha yang bergerak di bidang industri hilir dengan hulu atau sebaliknya.

c. Akuisisi konglomerat Akuisisi badan usaha yang tidak memiliki bidang bisnis yang sama atau tidak saling berkaitan

\section{Right Issue}

Right issue atau di Indonesia lebih dikenal sebagai Hak Memesan Efek Terlebih Dahulu (HMETD) mulai muncul di pasar modal Indonesia pada tahun 1992. Menurut Sunariyah (2011) right issue merupakan surat berharga yang memberikan hak bagi investor atau pemodal untuk membeli saham baru yang dikeluarkan emiten. Perusahaan mengeluarkan right issue bermaksud untuk menambah modal, selain itu untuk menghemat biaya penjamin emisi, serta menambah jumlah saham yang diperdagangkan (Mulatsih \& HarrySusanto, 2009). Menurut Darmadji (2011) dalam right issue, perseroan menawarkan hak (right) kepada pemegang saham yang ada untuk mendapatkan saham baru adalah salah satu cara yang ditempuh untuk menambah modal dengan rasio tertentu. Penerbitan right oleh emiten akan memberikan keuntungan bagi pemegang saham lama (existing shareholder) untuk mempertahankan proporsi atau presentase kepemilikan sahamnya. Saat penerbitan right issue, para pemegang saham lama akan ditawari saham baru dengan harga yang lebih rendah dari harga yang ditawarkan di pasar karena pemegang saham memiliki preemptive right yaitu hak memesan efek terlebih dahulu atas saham baru tersebut. Bila pemegang saham lama tidak membeli saham barunya, maka proporsi kepemilikan saham akan terdilusi atau menurun. Penambahan jumlah saham tersebut hanya ditawarkan kepada pemegang saham lama dengan jangka waktu tertentu, sehingga kebutuhan akan tetap terpenuhi dengan menambah modal sendiri.

\section{Abnormal Return}

Menurut Jogiyanto (2010), abnormal return merupakan kelebihan dari return (pengembalian) yang sesungguhnya terjadi (actual return) terhadap return (pengembalian) hasil normal. Abnormal return atau return normal merupakan return ekspektasi (expected return) atau return yang diharapkan oleh investor. Dengan demikian return tidak normal (abnormal return) adalah selisih antara return sesungguhnya yang terjadi dengan return ekspektasi. Apabila return yang sebenarnya terjadi (actual return) lebih tinggi dari return yang diharapkan (expected return) maka dapat dikatakan telah terjadi abnormal return dan terjadi selisih positif, tetapi apabila terjadi sebaliknya maka terdapat selisih negatif. Menurut Tandelilin (2010) Return tak normal adalah return aktual di sekitar periode peristiwa dikurangi return harapan atau prediksian pada periode peristiwa tersebut

\section{Pengembangan Hipotesis}

\section{Hubungan Akuisisi terhadap Abnormal return saham}

Hasil penelitian sebelumnya menunjukan adanya perbedaan signifikan abnormal return pada periode sebelum dan sesudah pengumuman merger dan akuisisi sehingga dapat dikatakan bahwa pengumuman tersebut memberikan pengaruh kuat untuk yang membuat 
pelaku pasar memutuskan untuk berinvestasi saham agar memeroleh return yang tinggi (Sundari, 2017). Restika (2013) menemukan bahwa tidak ada peningkatan terhadap kinerja perusahaan setelah pengumuman merger dan akuisisi. Berdasarkan dari teori dan hasil penelitian diatas maka dirumuskan hipotesis sebagai berikut :

$\mathrm{H}_{1}$ : Akuisisi berpengaruh terhadap abnormal return saham

\section{Hubungan right issue terhadap abnormal return saham}

Hasil penelitian terdapat perbedaan yang signifikan pada saat sesudah dan sebelum pengumuman right issue, volume perdagangan saham tidak memiliki perbedaan yang signifikan pada saat sebelum dan sesudah pengumuman right issue (Widyatmoko et al., 2018). Otieno (2015) yang menyatakan bahwa pengumuman right issue secara signifikan tidak memberikan perbedaan pada hasil dari abnormal return, tetapi dapat memberikan pengaruh yang cukup kuat dipasar saham. Hal ini dikarenakan konten informasi disekitar periode pengumuman kurang dapat dipastikan, sehingga akan dapat mempengaruhi reaksi investor dipasar saham. Berdasarkan dari teori dan hasil penelitian diatas maka dirumuskan hipotesis sebagai berikut :

$\mathrm{H}_{2}$ : Right Issue berpengaruh terhadap abnormal return saham

\section{METODOLOGI PENELITIAN}

Kerangka fikir merupakan keterkaitan antara teori-teori atau konsep yang mendukung dalam penelitian yang digunakan sebagai pedoman dalam menyusun sistematis penelitian (Saunders et al., 2009). Kerangka fikir menjadi pedoman peneliti untuk menjelaskan secara sistematis teori yang digunakan dalam penelitian. Penelitian ini memiliki kerangka konseptual yang dijelaskan pada gambar 2. Jenis penelitian yang digunakan dalam penelitian ini adalah kuantitaf menggunakan metode penelitian studi peristiwa (event study). Populasi dalam penelitian ini adalah perusahan yang terdaftar di Bursa Efek Indonesia periode tahun 2015-2019 sebanyak 627 perusahaan. Sampel yang digunakan menggunakan metode purpose sampling yang merupakan teknik pengambilan sampel non-probabilitas yang dilakukan secara purposif berdasarkan kriteria spesifik yang ditetapkan oleh peneliti serta sesuai dengan tujuan penelitian. Jenis data dalam penelitian ini adalah data sekunder dan bersifat historis data. Data tersebut berupa harga saham harian emiten yang dijadikan sampel penelitian pada periode pengamatan yang bersumber dari website Bursa Efek Indonesia serta sumber lainnya yang berkaitan dengan penelitian seperti, buku-buku referensi, literatur terdahulu sebagai data tambahan dalam penelitian. Teknik pengumpulan data yang digunakan dalam penelitian ini adalah dokumentasi. Dengan cara melihat pengumuman akuisisi dan right issue, dan harga saham di Bursa Efek Indonesia kemudian menghitung actual return dan abnormal return saham. 


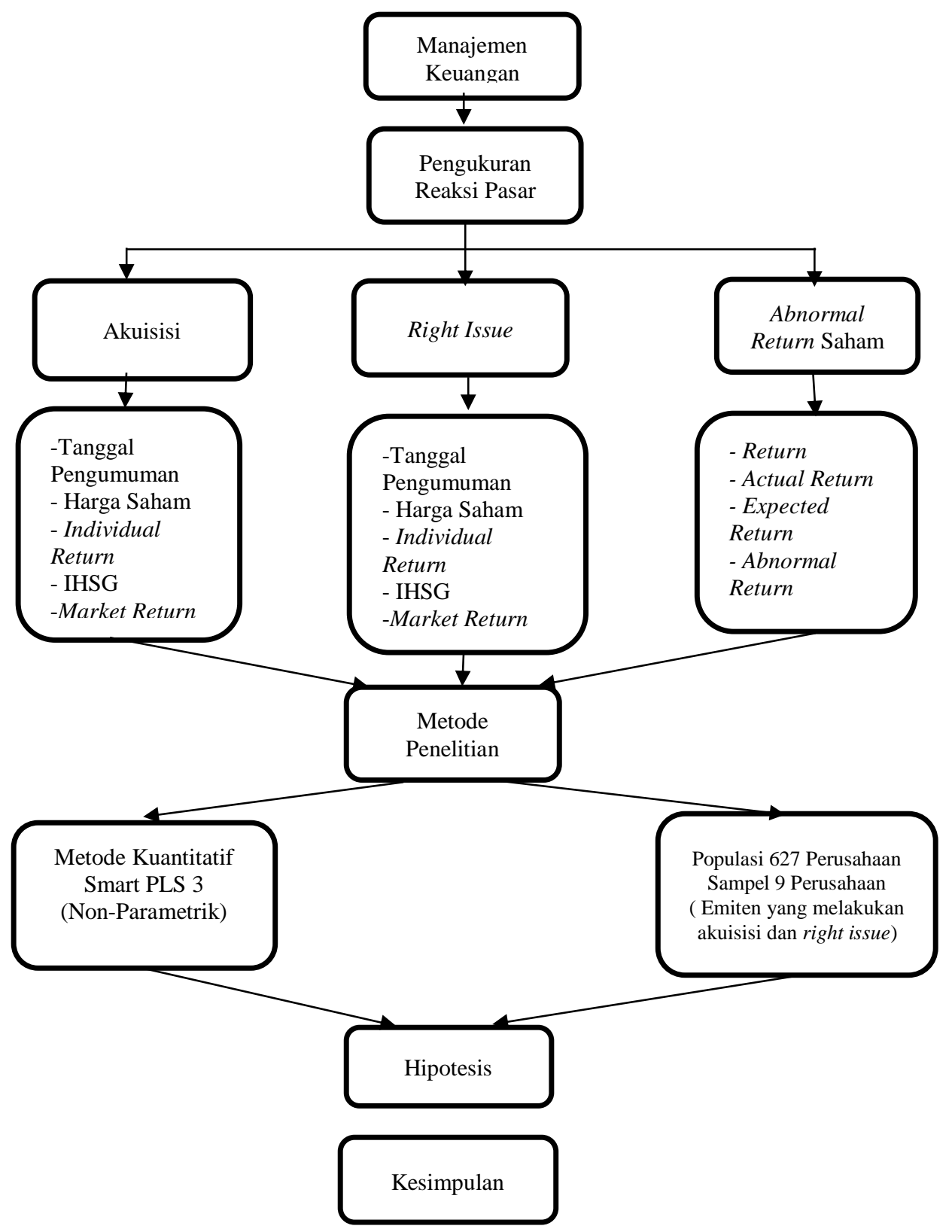

Gambar 2. Kerangka Fikir

\section{HASIL PENELITIAN}

\section{Uji hipotesis}

Pengujian hipotesis dilakukan untuk melihat ada atau tidaknya perbedaan signifikan abnormal return sebelum dan sesudah akuisisi dan right issue. Pengujian hipotesis pertama yaitu diduga terdapat perbedaan signifikan abnormal return saham sebelum dan sesudah pengumuman akuisisi pada perusahaan akuisitor yang terdaftar di Bursa Efek Indonesia periode tahun 2015-2019, dilakukan dengan uji Paired Sample T-Test. Pengujian hipotesis kedua yaitu diduga terdapat perbedaan signifikan abnormal return saham sebelum dan sesudah pengumuman right issue pada perusahaan yang terdaftar di Bursa Efek Indonesia periode tahun 2015-2019, dilakukan dengan uji Wilcoxon Signed Rank Test. 


\section{Uji Paired Sample T-Test pada average abnormal return sebelum dan sesudah akuisisi}

Tabel 3 Hasil Uji Paired Sample T-Test Paired Samples Statistics

\begin{tabular}{|l|l|r|r|r|r|}
\hline \multicolumn{7}{|c|}{ Paired Samples Statistics } \\
\hline Pair & AR Sebelum &,- 0046 & 9 & \multicolumn{1}{c|}{$\begin{array}{c}\text { Std. Error } \\
\text { Mean }\end{array}$} \\
\cline { 3 - 6 } 1 & AR Sesudah &, 0045 & 9 &, 00881 &, 00294 \\
\hline
\end{tabular}

\begin{tabular}{|c|c|c|c|}
\hline & $\mathrm{N}$ & Correlation & Sig. \\
\hline AR Sebelum \& AR Sesudah & & $\begin{array}{r}-, 818 \\
\end{array}$ &, 007 \\
\hline
\end{tabular}

\begin{tabular}{|c|c|c|c|c|c|c|c|c|c|}
\hline \multicolumn{10}{|c|}{ Paired Samples Test } \\
\hline & & \multicolumn{5}{|c|}{ Paired Differences } & \multirow[b]{3}{*}{$\mathrm{t}$} & \multirow[b]{3}{*}{ df } & \multirow{3}{*}{$\begin{array}{l}\text { Sig. (2- } \\
\text { tailed) }\end{array}$} \\
\hline & & \multirow[b]{2}{*}{ Mean } & \multirow{2}{*}{$\begin{array}{l}\text { Std. } \\
\text { Deviati } \\
\text { on }\end{array}$} & \multirow{2}{*}{$\begin{array}{l}\text { Std. } \\
\text { Error } \\
\text { Mean }\end{array}$} & \multicolumn{2}{|c|}{$\begin{array}{l}\text { 95\% Confidence } \\
\text { Interval of the } \\
\text { Difference } \\
\end{array}$} & & & \\
\hline & & & & & Lower & Upper & & & \\
\hline $\begin{array}{c}\text { Pair } \\
1\end{array}$ & $\begin{array}{c}\text { AR } \\
\text { Sebelum - } \\
\text { AR } \\
\text { Sesudah }\end{array}$ &,- 00907 &, 01573 &, 00524 &,- 02116 & ,00303 & $-1,729$ & 8 & ,122 \\
\hline
\end{tabular}

Sumber: output SPSS, diolah 2020.

Tabel 3 menunjukan hasil output uji Paired Sample T-Test pada abnormal return sebelum dan sesudah akuisisi. Pada bagian pertama (Paired Samples Statistics) menunjukan bahwa rata-rata (mean) sebelum akuisisi adalah 0,0046 dengan standar deviasi 0,00881 sedangkan sesudah akuisisi rata-rata (mean) adalah 0,0045 dengan standa deviasi 0,00769. Bagian kedua (Paired Samples Correlations) menghasilkan angka 0,818 dengan nilai probabilitas (sig). 0,007. Jika nilai probabilitas (sig). lebih kecil dari 0,05 (sig. < 0,05) maka terdapat hubungan secara nyata antar variabel. Jika nilai probabilitas lebih besar dari 0,05 (sig. > 0,05) maka tidak terdapat hubungan yang nyata antar variabel. Oleh karena nilai probabilitas didapat 0,007 lebih besar dari 0,005 maka, tidak terdapat hubungan antara abnormal return sebelum dan sesudah akuisisi. Bagian ketiga (Paired Samples Test), merupakan bagian utama dari hasil uji Paired Sample T-Test yang dapat diketahui melalui nilai signifikansi (2-tailed). Jika nilai signifikansi (2-tailed) lebih kecil dari 0,05 maka terdapat perbedaan yang signifikan, sebaliknya jika nilai sig (2-tailed) lebih besar dari 0,05 maka tidak terdapat perbedaan yang signifikan antar variabel. Pada bagian ketiga (Paired Sample Test) terlihat bahwa nilai signifikansi (2-tailed) adalah 0,122 dan lebih besar dari 0,05. Artinya, antara abnormal return sebelum dan sesudah akuisis tidak terdapat perbedaan yang signifikan. 


\section{Uji Paired Sample T-Test pada average abnormal return sebelum dan sesudah right issue}

Tabel 4. Hasil uji Wilcoxon Signed Rank Test

\begin{tabular}{|c|c|c|c|c|}
\hline \multicolumn{5}{|c|}{ Ranks } \\
\hline & & $\mathrm{N}$ & Mean Rank & Sum of Ranks \\
\hline \multirow{4}{*}{$\begin{array}{l}\text { AR Sesudah - AR } \\
\text { Sebelum }\end{array}$} & Negative Ranks & $4^{a}$ & 5,00 & 20,00 \\
\hline & Positive Ranks & $5^{b}$ & 5,00 & 25,00 \\
\hline & Ties & $0^{c}$ & & \\
\hline & Total & 9 & & \\
\hline $\begin{array}{l}\text { AR Sesuc } \\
\text { AR Sesuc } \\
\text { AR Sesun }\end{array}$ & $\begin{array}{l}\text { ah }<A R \text { Sebelum } \\
\text { ah }>A R \text { Sebelum }\end{array}$ & & & \\
\hline
\end{tabular}

\begin{tabular}{|l|r|}
\hline \multicolumn{2}{|c|}{ Test Statistics $^{\text {a }}$} \\
\hline & \multicolumn{1}{|c|}{ AR Sesudah - } \\
& AR Sebelum \\
\hline Z &,$- 296^{\mathrm{b}}$ \\
\hline &, 767 \\
\hline $\begin{array}{l}\text { Asymp. Sig. (2-tailed) } \\
\text { b. Bilcoxon Signed Ranks Test on negative ranks. }\end{array}$ \\
\hline
\end{tabular}

Sumber: output SPSS, diolah 2020.

Tabel 4. menunjukkan output uji Wilcoxon Signed Rank Test pada average abnormal return sebelum dan sesudah right issue. Pada bagian satu (ranks) hasil negative ranks menghasilkan nilai 4 di kolom $\mathrm{N}$, menunjukan bahwa ada 4 observasi sesudah yang kurang dari observasi sebelum dengan ata-rata ranking negatif 20. Hasil positive ranks ini menunjukan bahwa ada 5 observasi sesudah yang lebih besar dari observasi sebelum, dengan rata-rata ranking positif 25. Ties menunjukan bahwa tidak ada data yang sama antara sebelum dan sesudah akuisisi. Bagian kedua (test statistics) merupakan utama dalam uji Wilcoxon Signed Ranks Test. Jika nilai asymp.sig. (2-tailed) lebih kecil dari 0,05 maka terdapat perbedaan yang signifikan, sebaliknya jika asymp.sig (2-tailed) lebih besar dari 0,05 maka tidak terdapat perbedaan yang signifikan antar variabel. Hasil dari uji Wilcoxon Signed Rank Test pada abnormal return sebelum dan sesudah right issue, diperoleh nilai asymp. sig (2-tailed) 0,767. Nilai tersebut lebih besar dari 0,05 (0,767 > 0,005), maka tidak terdapat perbedaan yang signifikan antara abnormal return sebelum dan sesudah akuisisi.

\section{Pembahasan}

Berdasarkan hasil pengujian Hipotesis pertama dengan menggunakan Uji Paired Sample T-Test terhadap abnormal return pada periode sebelum dan sesudah pengumuman akuisisi diperoleh nilai probalilitas sebesar 0,122 . Nilai probabilitas ini jelas lebih besar dari 0,05 yang berarti mengindikasikan bahwa Hipotesis pertama ditolak sehingga tidak terdapat perbedaan yang signifikan abnormal return sebelum dan sesudah akuisisi.

Hasil analisis Uji Wilcoxon Signed Rank Test pada abnormal return sebelum dan sesudah right issue diperoleh nilai probalilitas sebesar 0,767. Nilai probabilitas ini jelas lebih besar dari 0,05 yang berarti mengindikasikan bahwa Hipotesis kedua ditolak 
sehingga tidak terdapat perbedaan yang signifikan abnormal return sebelum dan sesudah right issue. Pengujian terhadap abnormal return menunjukkan bahwa tidak terdapat perbedaan yang signifikan antara sebelum dan sesudah pengumuman akuisisi dan right issue. Hal ini menunjukkan bahwa pengumuman akuisisi dan right issue tersebut tidak mengandung informasi yang cukup untuk dapat memengaruhi investor dalam melakukan kegiatan investasinya.

Salah satu penyebab ketidaksignifikan ini adalah periode pengamatan yang terlalu singkat yaitu selama 11 hari. Pemilihan sampel mungkin j menjadi salah satu faktor penyebab tidak signifikan, karena pemilihan sampel yang tidak mempertimbangkan jenis perusahaan. Emiten yang menjadi sampel penelitian ini merupakan emiten yang beragam dari berbagai sektor. Dari sektor finance yaitu PT. MNC Kapital Indonesia, Tbk. Sektor infrastruktur, utilitas dan transportasi yaitu PT. Jasa Marga, Tbk dan PT. Buana Listya Tama, Tbk. Sektor pertambangan yaitu PT. Barito Pasifik, Tbk dan PT. Medco Energi Internatioanl, Tbk. Sektor industri yaitu PT. Inti Keramik Alamasri, Tbk dan PT. Trisula International, Tbk. Sektor pelayanan kesehatan yaitu PT. Siloam International Hospitals, Tbk. Dari sektor properti dan real estat adalah PT. Rimo International Lestari, Tbk.

Perusahaan yang menjadi sampel adalah perusahaan yang melakukan akuisisi dengan tujuan yang beragam, seperti PT. MNC Kapital Indonesia, Tbk yang melakukan akuisisi untuk memperkuat posisi perseroan sebagai perusahaan investasi yang terintegritas. PT. Rimo International Lestari, Tbk yang melakukan akuisisi dan beralih bisnis dari sektor ritel ke properti. PT. Medco Energi Internatioanl, Tbk yang melakukan akuisisi untuk memperkuat perseroan di sektor pembangkit tenaga listrik. PT. Jasa Marga, Tbk melakukan akuisisi untuk meningkatkan aksesbilitas jaringan jalan dalam melayani lalu lintas di koridor Trans Jawa. PT. Inti Keramik Alamasri, Tbk yang melakukan akuisisi untuk meningkatkan investasi aset, laba dan efisiensi biaya operasi bisnis. Right issue yang dilakukan perusahaan sampel, bertujuan untuk membiayai kegiatan akuisisi dan sisanya digunakan untuk menambah modal kerja.

Hasil temuan ini memperkuat bahwa pengumuman akuisisi maupun right issue yang dikeluarkan oleh perusahaan bereaksi negatif terhadap harga saham sehingga tidak memberikan pengaruh terhadap abnormal return. Bagi investor, informasi akuisisi maupun right issue dianggap tidak mempunyai kandungan informasi dan tidak memberikan dampak yang signifikan bagi perusahaan, sehingga mengakibatkan pasar tidak bereaksi atas pengumuman tersebut. Tidak adanya jaminan bahwa dana hasil right issue yang digunakan untuk membiayai akuisisi dan kegiatan akuisisi yang dilakukan emiten akan berdampak positif pada perusahaan, sehingga memberikan timbal balik yang positif kepada investor kedepannya, menjadi penyebab lain dari ketidaksignifikanya penelitian ini.

Secara kumulatif, pengumuman akuisisi dan right issue belum dapat memberikan kandungan informasi yang positif, Hal ini mengakibatkan secara keseluruhan pasar tidak bereaksi terhadap pengumuman akuisisi dan right issue. Analisa diatas sesuai dengan penelitian yang dilakukan oleh Mulatsihet (2009), Khairudin (2017) yang menyimpulkan bahwa pengumuman akuisisi dan right issue di respon secara negatif oleh investor. Hasil penelitian ini bertolak belakang dengan penelitian yang dilakukan oleh Adnan (2016) dan Joga (2010), yang menyimpulkan bahwa investor merespon positif terhadap pengumuman akuisisi dan right issue. Ketidak-konsistenan penelitian ini apabila dibandingkan dengan penelitian di atas dikarenakan perbedaan karakteristik pasar dan periode pengamatan. Hal ini dikarenakan kondisi pasar di luar negeri sudah 
mencerminkan pasar efisiensi bentuk kuat, sedangkan Bursa Efek di Indonesia tergolong pada pasar modal yang sedang berkembang (emerging market). Kondisi ini dikarenakan adanya kemungkinan investor di pasar mencari keuntungan jangka pendek dengan melakukan aksi jual pada saat harga saham tinggi.

\section{KESIMPULAN}

Hasil penelitian pertama menghasilkan bahwa hipotesis pertama ditolak, sehingga dapat disimpulkan tidak terdapat perbedaan yang signifikan abnormal return sebelum dan sesudah pengumuman akuisisi. Hasil ini mengindikasikan bahwa pengumuman akuisisi tidak berpengaruh pada abnormal return saham. Hasil penelitian kedua menghasilkan bahwa hipotesis kedua ditolak, sehingga dapat disimpulkan tidak terdapat perbedaan yang signifikan abnormal return sebelum dan sesudah pengumuman right issue. Hasil ini mengindikasikan bahwa pengumuman right issue tidak berpengaruh pada abnormal return saham. Hal ini dapat dimungkinkan bahwa kandungan informasi pengumuman right issue tidak memberikan pengaruh yang cukup kuat kepada investor. Selain itu kandungan informasi yang di dapat oleh investor masih bersifat asimetris dan hanya sedikit investor yang memiliki informasi lebih untuk mendapatkan abnormal return, sehingga investor tidak banyak memberikan reaksi di pasar saham setelah adanya pengumuman right issue

\section{DAFTAR PUSTAKA}

Adnan, A. T. M., Hossain, A., Adnan, A., \& Hossain, A. (2016). Impact of M\&A announcement on acquiring and target firm's stock price: An event analysis approach. International Journal of Finance and Accounting, 5(5), 228-232.

Astria, N. (2012). Analisis dampak pengumuman merger dan akuisisi terhadap abnormal return saham perusahaan akuisitor yang terdaftar di BEI tahun 2006-2008. Jurnal Ilmiah Mahasiswa FEB, 1(2).

Darlis, E. (2011). Dampak Publikasi Akuisisi Pada Perusahaan Pengakuisisi. Jurnal Ekonomi, 19(04).

Darmadji, T., \& Fakhruddin, H. M. (2011). Pasar modal di indonesia. Jakarta: Salemba Empat.

Epriyeni, A. (2014). Pengaruh Pengumuman Merger, Akuisisi dan Right issue Terhadap Abnormal return Saham di Bursa Efek Indonesia.

Godfrey, N. (2008). Why Is Competition Important for Growth and Poverty Reduction ? Forum American Bar Association, 1-12.

Haryani, P. Y. (2013). Korelasi antara Pengembangan Karir dengan Motivasi Kerja dan Keinginan Untuk Pensiun Dini. Buletin Studi Ekonomi.

Hidayat, R. (2013). Analisis Dampak Sebelum, Sesudah Pengumuman Merger dan Akuisisi Terhadap Abnormal Return dan Volume Perdagangan Saham pada Perusahaan yang Terdaftar di BEI. Jurnal Universitas Maritim Raja Ali Haji Tanjungpinang.

Joga, J. (2010). Pengaruh Pengumuman Right Issue Terhadap Kinerja Saham Dan Likuiditas Saham Di Bursa Efek Indonesia. Riset Manajemen Dan Akuntansi STIE Atma Bhakti, 1(1), 221272.

Jogiyanto, H. M. (2010). Teori portofolio dan analisis investasi. Edisi Ketujuh. BPFE. Yogyakarta. 
Khairudin, M., \& Wulandari, T. R. (2017). Merger, Akuisisi dan Kinerja Saham Perusahaan di Bursa Efek Indonesia (BEI). Jurnal Akuntansi Dan Bisnis, 17(1), 2737.

Lianawati, N. K., \& Darmayanti, N. P. A. (2015). Reaksi Pasar Terhadap Peristiwa Right Issue di Bursa Efek Indonesia. E-Jurnal Manajemen Universitas Udayana, 4(12).

Mulatsih, L. S., \& Harry-Susanto, M. (2009). Analisis Reaksi Pasar Modal Terhadap Pengumuman Right Issue di Bursa Efek Jakarta (BEJ)(Pengamatan Terhadap Return, Abnormal Return, Security Return Variability dan Trading Volume Activity). WACANA, Jurnal Sosial Dan Humaniora, 12(4), 646-661.

Otieno, O. D., \& Ochieng, D. E. (2015). The effects of Rights Issue Announcements on Stock Returns for Firms Listed at the Nairobi Securities Exchange. International Journal of Education and Research, 3(9), 411-426.

Pratama, I. G. S. (2014). Analisis Perbandingan Abnormal Return Saham Sebelum dan Sesudah Pengumuman Right Issue. E-Jurnal Manajemen Universitas Udayana, 3(1).

Restika, S. M. (2013). Kinerja Keuangan Sebelum dan Sesudah Merger: Bukti Empiris dari Industri Perbankan Indonesia. Jurnal Ilmu Dan Riset Akuntansi, 1(2), 227-246.

Saunders, M., Lewis, P., \& Thornhill, A. (2009). Research methods for business students. Pearson education.

Sudana, I. M. (2011). Manajemen keuangan perusahaan teori dan praktik. Jakarta: Erlangga.

Sundari, R. I. (2017). Kinerja Merger dan Akuisisi pada Perusahaan Go Public. Telaah Bisnis, 17(1).

Tandelilin, E. (2010). Portofolio dan Investasi: Teori dan aplikasi. Kanisius.

Tarigan, P. P. Y., \& Pratomo, W. A. (2015). Analisis Dampak Merger dan Akuisisi Terhadap Abnormal Return dan Kinerja Keuangan Pada Perusahaan yang Terdaftar di Bursa Efek Indonesia. Jurnal Ekonomi Dan Keuangan, 3(3), 14841.

Widyatmoko, M. K., Mardani, R. M., \& Salim, A. (2018). Pengaruh Pengumuman Right Issue Terhadap Abnormal Return Dan Volume Perdagangan Saham (Studi Kasus Pada Perusahaan Asuransi yang Terdaftar di Bursa Efek Indonesia Periode 20112015). Jurnal Ilmiah Riset Manajemen, 7(4).

www.ksei.co.id

www.kppu.go.id 